\title{
Oxidative cyclization of $\gamma$-alkylidene butenolides. Stereoselective preparation of spirolactones
}

\author{
Raquel Galán-Fernández, David Clemente-Tejeda, and Francisco A. Bermejo* \\ Departamento de Química Orgánica, Facultad de Ciencias Químicas. Plaza de la Merced s/n, \\ Universidad de Salamanca, 37008 Salamanca, Spain \\ E-mail:fcobmjo@usal.es
}

\begin{abstract}
A new route to 1,6-dioxaspiro[4.4]non-3-en-2-ones is established by bromoetherification of dihydroxybutenolides. An asymmetric total synthesis of 8-epi-crassalactone D starting from methyl cinnamate has been accomplished.
\end{abstract}

Keywords: $\gamma$-Spirolactones, oxidative cyclization, stereoselective synthesis, crassalactones, bromoetherification

\section{Introduction}

Spiro- $\gamma$-lactones constitute an important class of oxygen-containing heterocyclic compounds, and such groups can be found in many biologically active natural products. ${ }^{1}$ Among them, the 1,6dioxaspiro[4.4]non-3-en-2-ones constitute a family that have attracted our attention very recently due to their structural originality and biological activity. For example, the styryl-lactone (+)-crassalactone D (1a, Figure 1) has recently been isolated from an extract of the leaves and twigs of Polyalthia crassa Parker (Annonaceae), and its structure was determined on the basis of spectroscopic methods. Single-crystal X-ray analysis and the Mosher ester method were used to confirm its absolute stereochemistry. Spirolactone 1a showed broad cytotoxic activity against murine lymphocytic leukemia, human colon, nasopharyngeal, lung and breast carcinomas. ${ }^{2}$ Pyrenolide D 2, however, was isolated from the phytopathogenic fungus Pyrenophora teres (Diedicke) Drechsler (FO 7508), ${ }^{3}$ and its absolute configuration was determined by pioneer synthetic work in this field. ${ }^{4}$ Although 2 , like other pyrenolides, was not active against fungi, it was found to be cytotoxic toward HL-60 cells at $\mathrm{IC}_{50} 4 \mu \mathrm{g} / \mathrm{ml}$.

(+)-Massarinolin A 3 is a bioactive sesquiterpenoid isolated by Gloer et al. from liquid cultures of the aquatic fungus Massarina tunicata Shearer \& Fallah. ${ }^{5}$ It shows biological activity against Bacillus subtilis (ATCC 6501) and Staphylococcus aureus (ATCC 29213). It appears to be biosynthesized from a farnesyl-type precursor and even though its relative stereochemistry was deduced by spectroscopic methods its absolute stereochemistry remains a challenge for 
synthetic chemists. The ring system found in compound $\mathbf{3}$ has previously been encountered only in expansolides A and B (4, and 5), reported as metabolites of Penicillium expansum. ${ }^{6}$ Their absolute configuration was established using the modified Mosher method. ${ }^{7}$

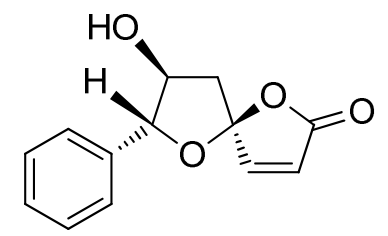

(+)-crassalactone D (1a)

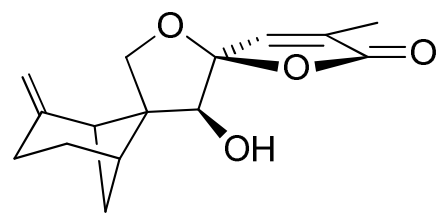

(+)-massarinolin A (3)

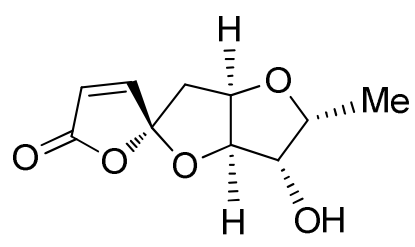

(+)-pyrenolide D (2)

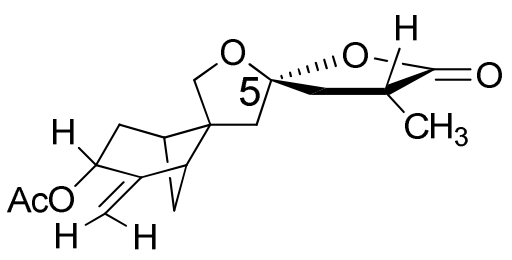

expansolide A (4): $5 R$ expansolide $B(5): 5 S$

Figure 1. Biologically active spiro $\gamma$-lactones.

Although pioneer synthetic approaches to spirobutenolides have been reviewed by Knight in $1994,{ }^{8}$ further synthetic efforts in this topic have been reported. ${ }^{9}$ The first total synthesis of (+)pyrenolide D 2 started from tri- $O$-acetyl-D-galactal and was reported by Gin et al. in 2001. This pioneer synthetic work led to the absolute stereochemical assignment of $2 .{ }^{10}$ The enantiospecific synthesis of four hydroxylated analogues of 2 was reported by Robertson et al. ${ }^{11}$ This synthetic approach started from D-glucose and was based on furan oxidative spirocyclization. Shortly afterwards, Vassilikogiannakis et al. reported the photooxygenation of 2-( $\gamma$-hydroxyalkyl)furans as a newly developed technology applied to the synthesis of $\gamma$-spiroketal $\gamma$-lactones such as (+)crassalactone D (1a), and three different epimers of pyrenolide D, $2 .{ }^{12}$ The asymmetric total synthesis of (+)-crassalactone D from the commercially available 3-bromo-1-phenyl-1-propene was published by Yang et al. in 2009. Their successful synthesis was elegantly achieved by employing an oxidative spirocyclization of a dihydroxylated 2-substituted furan as the key step. Two close analogues of (+)-crassalactone D 1a, have also been prepared in the course of the

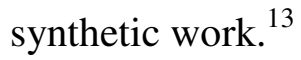

\section{Results and Discussion}

In order to test whether the bromoetherification of hydroxybutenolides might afford an efficient way towards the synthesis of 1,6-dioxaspiro[4.4]non-3-en-2-ones of the type 1a, we decided to 
study the stereochemical outcome of the oxidative cyclization reaction of 7-epi-goniobutenolides A and B. (Figure 2)

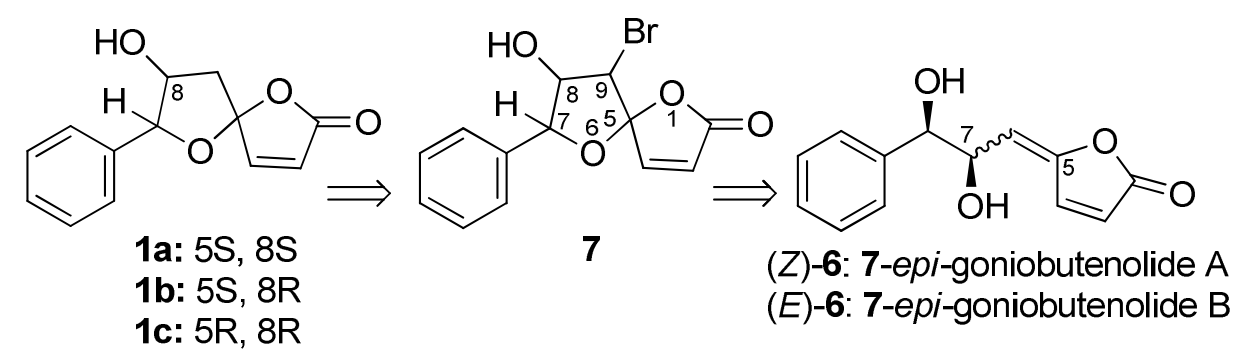

Figure 2. Retrosynthetic analysis of crassalactones.

The preparation of both stereoisomers of 7-epi-goniobutenolide $\mathbf{6}$ was accomplished by following pioneer synthetic work in this field. ${ }^{14}$ Isolation of the aldehyde $\mathbf{1 1}$ afforded the opportunity to assay the vinylogous Mukaiyama aldol reaction using the 2-silyloxyfuran 12a (TMSOF) in the presence of Lewis acids such as $\mathrm{TiCl}_{4}$ or $\mathrm{SnCl}_{4}{ }^{15}$ The reaction yielded a mixture of stereoisomers 13a and 13b with similar results $(72 \%$ yield and a moderate stereoselectivity, favouring the threo adduct 13a: 13b = 1.7: 1) (Scheme 1).

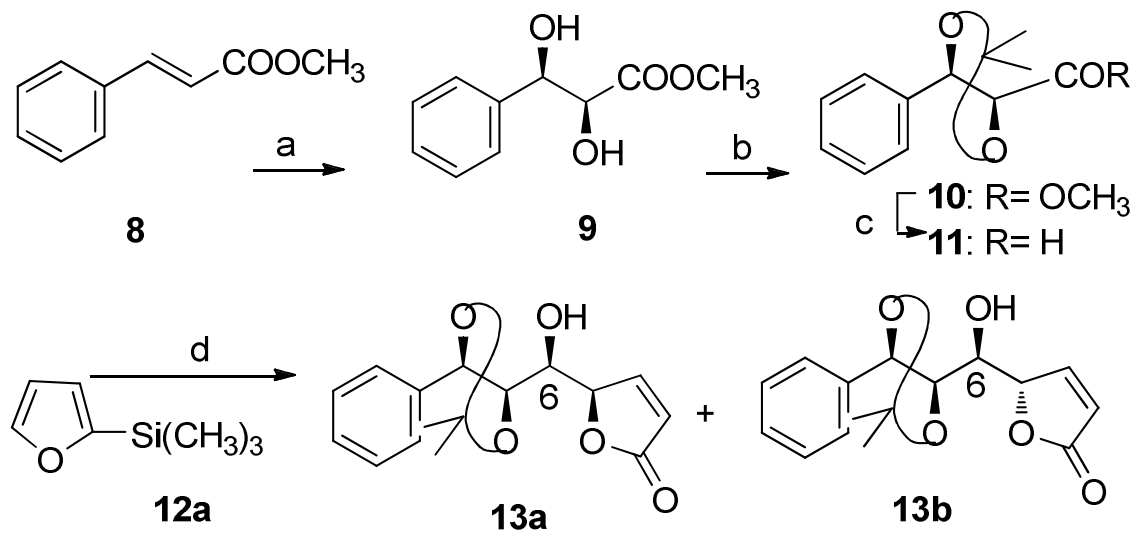

a) $\mathrm{ADmix}-\beta, \mathrm{CH}_{3} \mathrm{SO}_{2} \mathrm{NH}_{2}, \mathrm{tBuOH} / \mathrm{H}_{2} \mathrm{O}, \mathrm{rt}(87 \%)$. b) $\left(\mathrm{CH}_{3}\right)_{2} \mathrm{C}\left(\mathrm{OCH}_{3}\right)_{2}, p-\mathrm{TsOH}, \mathrm{CH}_{2} \mathrm{Cl}_{2}(90 \%)$

c) DIBALH, $-78^{\circ} \mathrm{C}(94 \%)$ d) $\mathrm{TiCl}_{4}$ or $\mathrm{SnCl}_{4}$, diethyl ether, $-78^{\circ} \mathrm{C}(72 \%)$.

Scheme1. Vinylogous aldol reaction on cinnamyl aldehyde derivatives.

A possible explanation for the preference towards 13a may lie in hydrogen bonding formation between the hydroxy function and the lactone oxy group (see Figure 3). ${ }^{16}$ The stereoselective formation of 13a in the vinylogous Mukaiyama aldol reaction led us to undertake computational studies with a view to determining the the relative stability of both isomers : 13a and 13b. After a conformational search performed with MM2, the lower energy conformer 13a 
was found to be $4.63 \mathrm{kcal} / \mathrm{mol}$ more stable than 13b. Additionally, the hydrogen bonding formation for 13a, for a O-H distance of $\mathrm{d}$ : $2.269 \AA$, was seen to be more feasible in comparison with the value of $\mathrm{d}$ : $3.872 \AA$ obtained for the same O-H distance in $\mathbf{1 3 b}$.
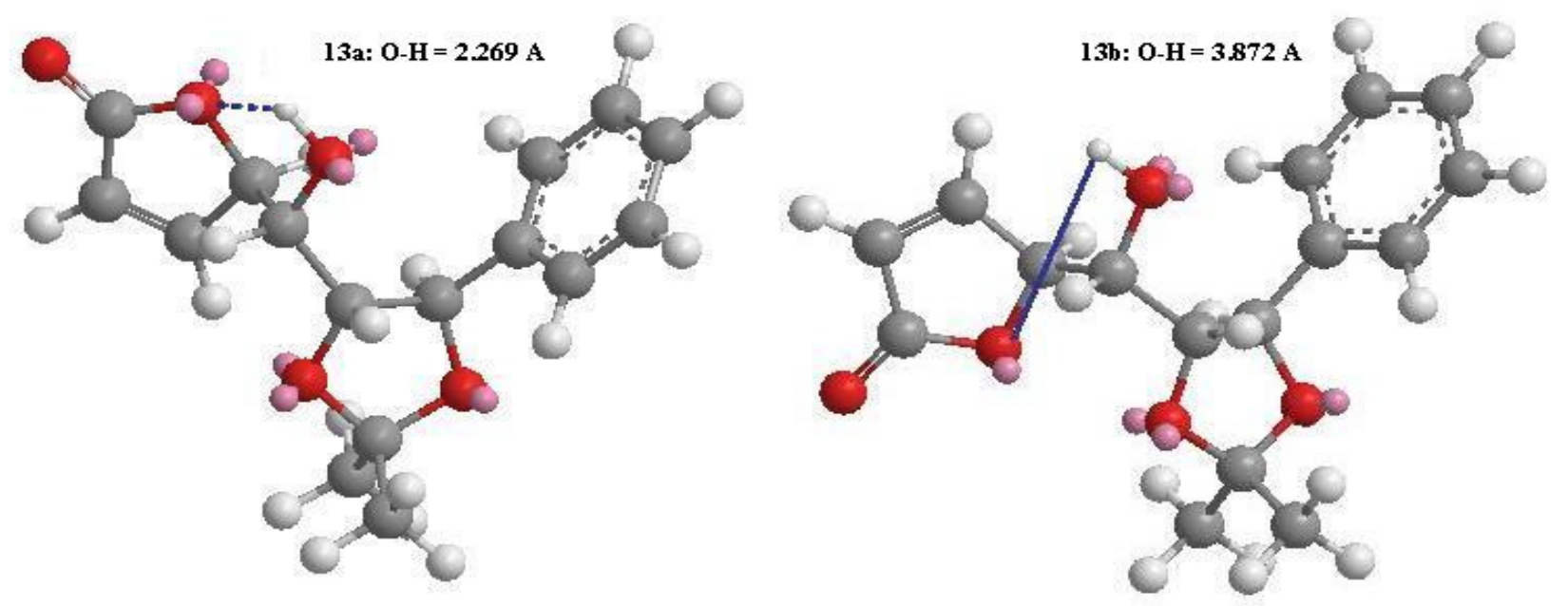

Figure 3. MM2 calculations for 13a and $13 \mathbf{b}$ structures.

Elimination of the hydroxyl function on C-6 in both isomers 13a and $\mathbf{1 3 b}$ required the transformation into the corresponding acetates $(\mathbf{1 4 a}$ and $\mathbf{1 4 b})$ and further treatment with base (Scheme 2). Treatment of $\mathbf{1 3 b}$ with acetic anhydride in pyridine led to the isolation of acetate $\mathbf{1 4 b}$ in $82 \%$ yield. Elimination of the acetate was accomplished by treatment with DBU and allowed us to isolate the butenolide 15a in quantitative yield. In the case of 13a, however, the use of dimethylaminopyridine (DMAP) to obtain the acetate 14a was necessary. The reluctance of the hydroxyl function to undergo the transformation into the acetate in this case may be due to the above-mentioned formation of hydrogen bonding with the lactone oxy function. Chromatographic separation of the crude product on silica gel led to the recovery of the starting material, and the desired product, 14a, with $25 \%$ and $68 \%$ yields respectively. Treatment of 14a with DBU led to the elimination product 15a, with $65 \%$ yield. It is known that this elimination takes place through an $\mathrm{E}_{1} \mathrm{cb}$ mechanism, and we assume that the convergent stereoselectivity obtained in both cases would mostly be due to stereoelectronic factors, which may be explained in terms of electronic repulsion between the lactone oxygen lone pairs and those of acetonide functionality, working on an identical intermediate. ${ }^{17}$

The deprotection of acetonide 15a took place smoothly without epimerization by treatment with $p$-toluenesulfonic acid in methanol and we were able to isolate the 7-epi-goniobutenolide (E)-6 in $73 \%$ yield. 


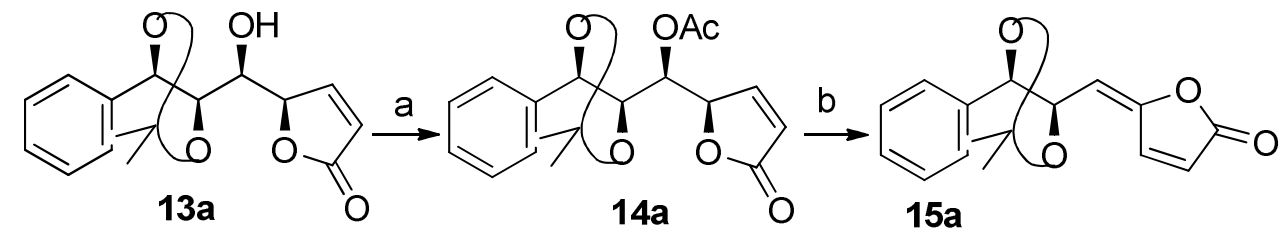

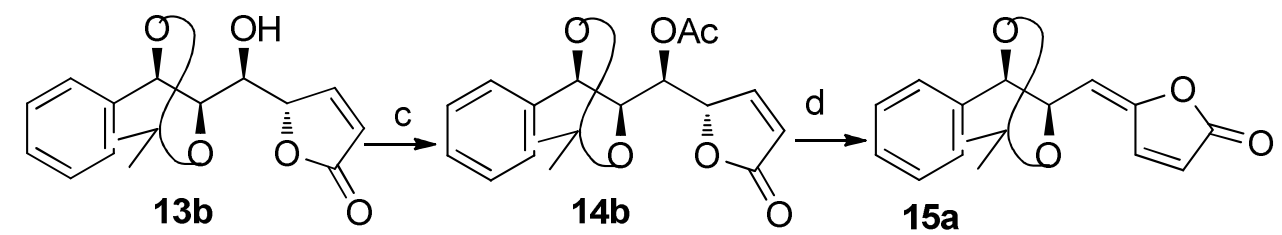

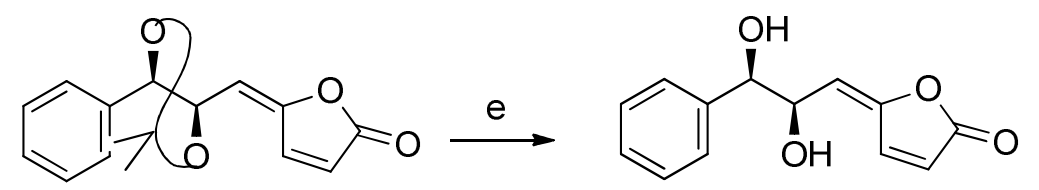

$15 a$

(E)-6

a) $\mathrm{Ac}_{2} \mathrm{O}$, pyr, DMAP, $\mathrm{CH}_{2} \mathrm{Cl}_{2}(68 \%)$. b) DBU (65\%). c) $\mathrm{Ac}_{2} \mathrm{O}, \mathrm{pyr}, \mathrm{CH}_{2} \mathrm{Cl}_{2}$ (82\%). d) DBU $(100 \%)$ e) $p$-TsOH, $\mathrm{MeOH}(73 \%)$.

Scheme 2. Synthesis of butenolide $(E)-6$.<smiles>CCOC(/C=C/c1ccccc1)OCC</smiles>

$17 a$

$17 b$

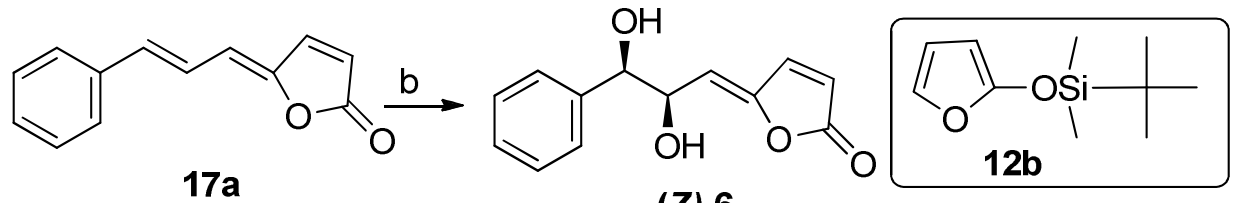

$17 a$

(Z)-6

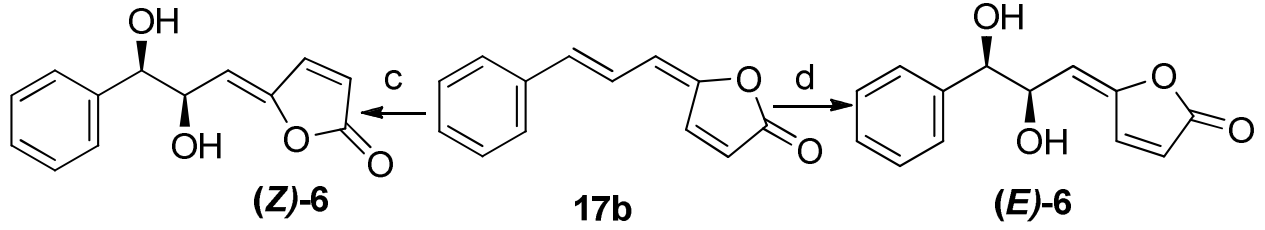

a) $\mathbf{1 2 b}, \mathrm{TiCl}_{4}$ then $\mathrm{KOAc}, \mathrm{AcOH}$. b) ADmix $-\beta, 0{ }^{\circ} \mathrm{C}$ or rt. c) ADmix $-\beta 24 \mathrm{~h}, \mathrm{rt}(82 \%)$. d) ADmix$\beta 24 \mathrm{~h}, 0^{\circ} \mathrm{C}(80 \%)$.

Scheme 3. Asymmetric synthesis of butenolides (Z)- and (E)-6.

Access to both isomers 13a and 13b was achieved following a modified previously-reported procedure $^{14 \mathrm{c}}$ starting from the cinnamyl aldehyde diethyl acetal $\mathbf{1 6}$ (Scheme 3). The trienes $\mathbf{1 7 a}$ and 17b were obtained at a 1: 1 ratio in $87 \%$ combined yield. The $E$ - and $Z$ - isomers, whose stereochemistry was established by NOE experiments, were readily separated by flash 
chromatography. The dihydroxylation of 17a under standard conditions afforded (Z)-6 in $85 \%$ yield and $98 \%$ ee. The other isomer 17b, however, yielded either isomer $(Z)-\mathbf{6}$ or $(E)-\mathbf{6}$ depending on the reaction temperature, in both cases with high yields (82\% and 80\%, respectively). The formation of $(\mathrm{Z})-\mathbf{6}$ took place when the reaction was performed at room temperature and can be explained in terms of isomerisation occurring under the reaction conditions and concomitant formation of a hydrogen bonding between the hydroxyl function on C-6 and the furanone oxy function which renders this stereoisomer more stable.

With both stereoisomers in our hands $(E)$ - and $(Z)-6$, we were ready to study the spirocyclization under oxidative conditions and establish the stereochemical outcome of the cyclization process (Scheme 4). Treatment of both isomers $(E)$ - and $(Z)-6$ with N-bromosuccinimide and sodium bicarbonate in chloroform at $0{ }^{\circ} \mathrm{C}$ afforded the same mixture of hydroxybromolactones, $7 \mathbf{a}: \mathbf{7 b}=3: 1$, in moderate yields $\left(62 \%\right.$ and $65 \%$, respectively). ${ }^{19}$

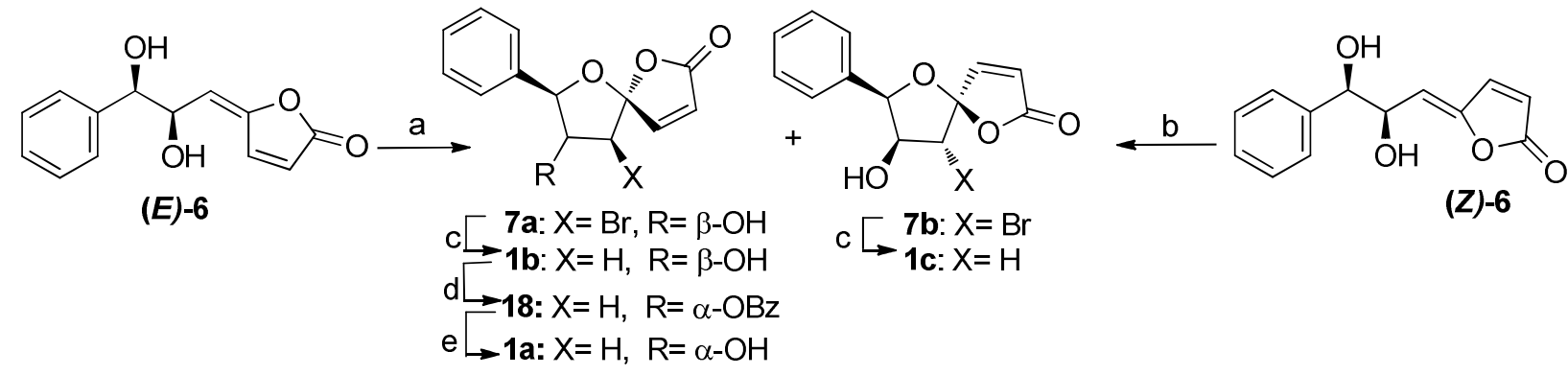

a) NBS, $\mathrm{NaHCO}_{3}, 0{ }^{\circ} \mathrm{C}, 48 \mathrm{~h}(70 \%)$. b) $\mathrm{NBS}, \mathrm{NaHCO}_{3}, 0{ }^{\circ} \mathrm{C}, 72 \mathrm{~h}(55 \%)$. c) nBu $\mathrm{nu}_{3} \mathrm{SnH}, \mathrm{AIBN},(100 \%)$. d) $\mathrm{Ph}_{3} \mathrm{P}, \mathrm{DEAD}, \mathrm{BzOH},(75 \%)$. e) Ref. 13.

Scheme 4. Oxidative cyclization of dihydroxy butenolides.

The reaction mixture proved to be chromatographically unresolvable on a flash column of silica gel. However, the structural assignment was possible by full spectroscopic analysis of the reaction mixture, which included COSY, ROESY, HMQC and HMBC spectra.

Structural assignment of 7a was based on the multiplicity found for the hydrogen atoms on C9 at $\delta=4.82 \mathrm{ppm}(\mathrm{d}, J=4 \mathrm{~Hz}), \mathrm{C} 8$ at $\delta=4.62 \mathrm{ppm}\left(\mathrm{dd}, J_{1}=J_{2}=4 \mathrm{~Hz}\right)$, and C7 at $\delta=5.51 \mathrm{ppm}$ (d, $J=4 \mathrm{~Hz}$ ), which suggests the cis stereochemistry for the three hydrogen atoms (Scheme 5). Additionally, the absence of correlation between the protons at C9 and C4 suggests the trans stereochemistry between the bromo and the lactone oxy functions. In the case of $\mathbf{7 b}$, however, the hydrogen at C9 appears as a singlet centered at $\delta=4.48 \mathrm{ppm}$, which suggests the trans stereochemistry with respect to the $\mathrm{OH}$ function on $\mathrm{C} 8$. Again, the absence of correlation between the protons at $\mathrm{C} 9$ and $\mathrm{C} 4$ suggests the trans relationship between the bromine and the lactone oxygen.

From a mechanistic point of view, the formation of $\mathbf{7 a}$ and $\mathbf{7 b}$ with the exclusion of $\mathbf{7 d}$ and 7c respectively obeys the stereoelectronic effect that is developed at the transition state of the 
bromoetherification reaction: the electronic repulsion between the electronic lone pairs on the bromine and the lactone oxygen.

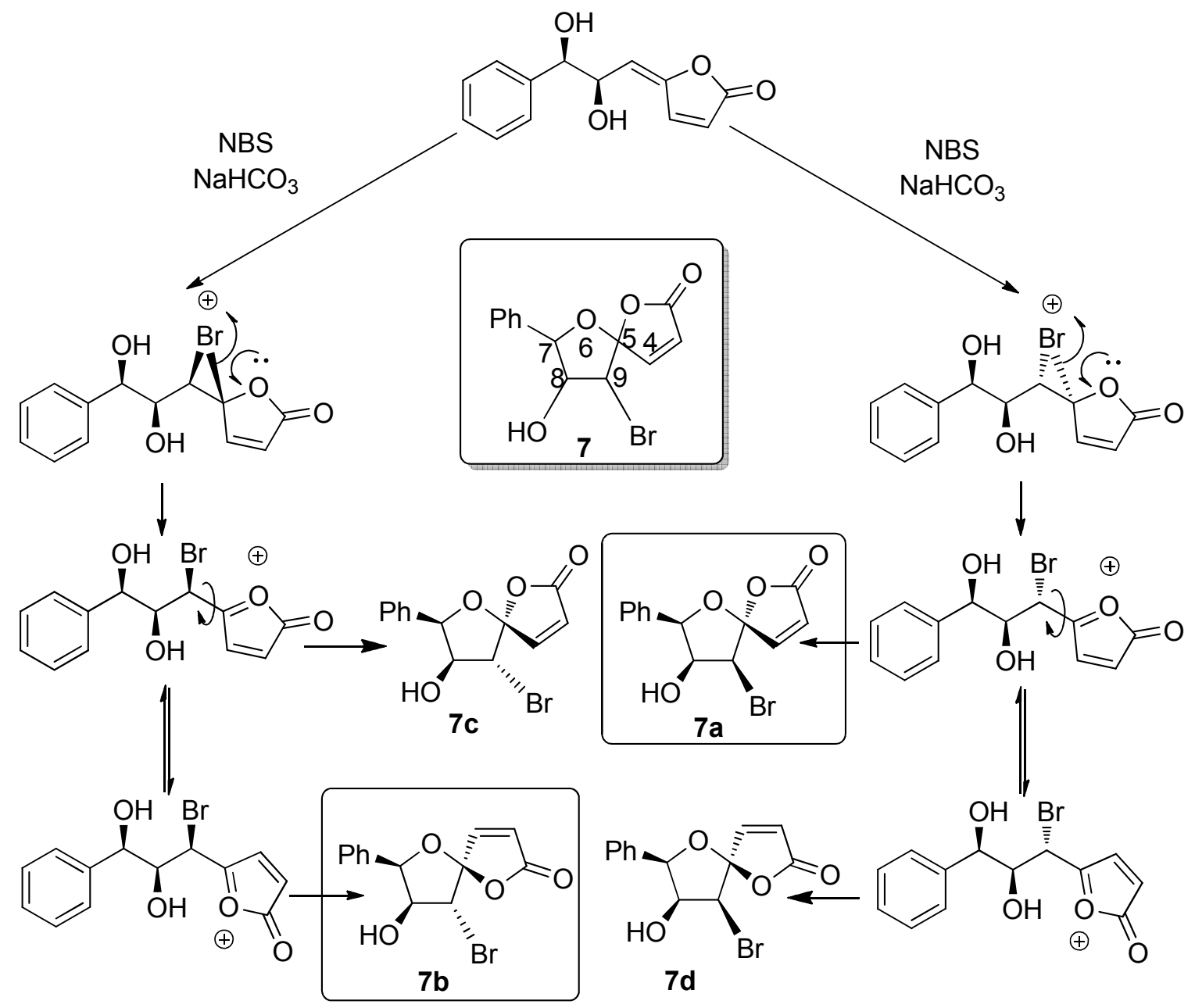

Scheme 5. Mechanism of formation of the spirobutenolides $\mathbf{7 a}$ and $\mathbf{7 b}$.

The formation of bromolactone 7a as the major isomer of the reaction mixture with respect to $\mathbf{7 b}$ can mainly be assigned to a stereoelectronic effect (Figure 4). ${ }^{20}$ Although the cyclization via antiperiplanar attack through the transition state TS-2 should be easier than that with the synclinal orientation (TS-1), the strong steric hindrance developed between the bromine atom and the C4-C5 bond of the furanone nucleus in TS-2 helps to rationalise the formation of the major isomer 7a from TS-1, which is much less sterically hindered.

Treatment of the bromolactones $\mathbf{7 a}$ and $\mathbf{7 b}$ with tri-n-butyltin hydride in refluxing toluene afforded the 8-epi-crassalactone D 1b, and 5,8-epi-crassalactone D 1c, in quantitative yields. The hydroxyspirolactones $\mathbf{1 b}$ and $\mathbf{1 c}$ were obtained at the same $(3: 1)$ ratio and were separated by flash chromatography on silica gel. Treatment of $\mathbf{1 b}$ under Mitsunobu conditions ${ }^{21}$ led to the isolation of the benzoate $\mathbf{1 8}$ with $\mathbf{7 5 \%}$ yield. Since the transformation of the benzoate $\mathbf{1 8}$ into 
(+)-crassalactone D 1a, has been recently accomplished by Yang et al, ${ }^{13}$ our present contribution may also be considered as a formal total synthesis of the biologically active compound.
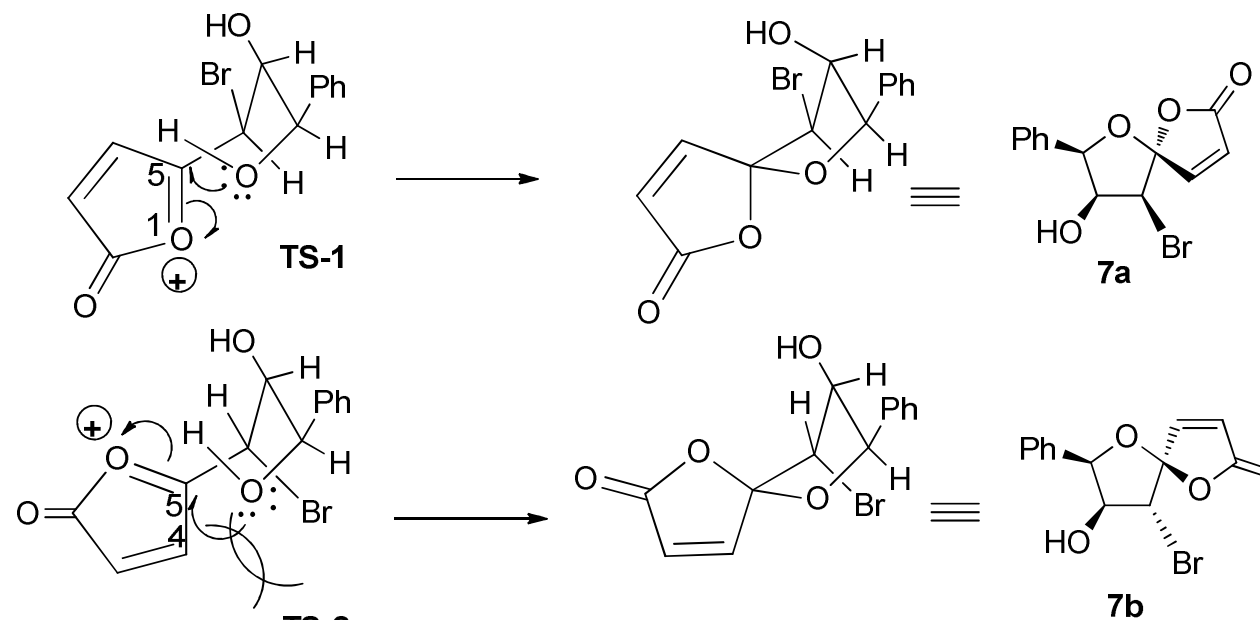

TS-2
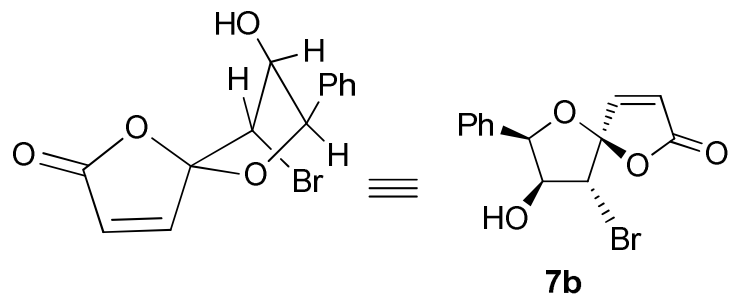

Figure 4. Stereoselective formation of 7a.

\section{Conclusions}

In summary: we have developed a new route to 1,6-dioxaspiro[4.4]non-3-en-2-ones through the oxidative cyclization of hydroxybutenolides. The bromoetherification reaction of 7-epigoniobutenolides $\mathbf{A}[(Z)-\mathbf{6}]$ and $\mathbf{B}[(E)$-6] afforded a mixture of bromospirolactones $7 \mathbf{a}$ and $7 \mathbf{b}$ in a 3:1 ratio, which was reduced by tributyltin hydride to afford the target molecules $\mathbf{1 b}$ and 1c. After chromatographic separation of the reaction mixture, the stereochemical outcome of the cyclisation reaction was elucidated by full spectroscopic analysis.

\section{Experimental Section}

General. Melting points are uncorrected. ${ }^{1} \mathrm{H}-\mathrm{NMR}$ spectra were measured at either 200 or 400 $\mathrm{MHz}$ and ${ }^{13} \mathrm{C}$-NMR were measured at 50 or $100 \mathrm{MHz}$ in $\mathrm{CDCl}_{3}$ and referenced to TMS $\left({ }^{1} \mathrm{H}\right)$ or solvent $\left({ }^{13} \mathrm{C}\right)$, except where indicated otherwise. IR spectra were recorded for samples in $\mathrm{CHCl}_{3}$ solution on $\mathrm{NaCl}$ plates, unless otherwise stated, with an FT-IR instrument. HRMS determinations (EI) were recorded at the Mass Spectrometry Service of the University of Salamanca, Spain. Microanalyses were performed on a Perkin-Elmer 240-B analyzer.

All reactions were conducted under a positive pressure of argon, utilizing standard bench-top techniques for handling of air-sensitive materials. Chemicals and solvents were obtained from commercial sources and used as received with the exception of benzene, toluene and dioxane 
which were distilled from sodium and benzophenone. Yields reported are for chromatographic pure isolated products unless stated otherwise.

(2S,3R)-Methyl 2,3-dihydroxy-3-phenylpropanoate (9). Methyl trans-cinnamate 8 (2.17 g, $13.38 \mathrm{mmol})$ was added to a solution of $\mathrm{ADmix}-\beta(18.73 \mathrm{~g})$ and $\mathrm{CH}_{3} \mathrm{SO}_{2} \mathrm{NH}_{2}(1.27 \mathrm{~g}, 13.38$ $\mathrm{mmol})$ in $\mathrm{H}_{2} \mathrm{O} / \mathrm{tBuOH}(100 \mathrm{~mL}, 1: 1)$. The reaction mixture was stirred for 14 hours at room temperature. Then $\mathrm{Na}_{2} \mathrm{SO}_{3}(12 \mathrm{~mL}, 0.5 \mathrm{M})$ was added and the mixture was stirred for an additional hour. The reaction mixture was extracted with ethyl acetate, and the combined organics layers were washed with brine and dried over anhydrous $\mathrm{Na}_{2} \mathrm{SO}_{4}$, and the solvent was evaporated under reduced pressure. The crude product was purified by flash chromatography, using hexane/Ethyl acetate (1:1) as eluent, to afford $9(2.29 \mathrm{~g}, 87 \%)$ as a white solid. Mp 125$127{ }^{\circ} \mathrm{C} .[\alpha]_{\mathrm{D}}{ }^{20}:-10.06\left(\mathrm{c} 0.75, \mathrm{CHCl}_{3}\right) .{ }^{1} \mathrm{H} \mathrm{NMR}\left(\mathrm{CDCl}_{3}\right): \delta 3.67(\mathrm{~s}, 3 \mathrm{H}), 4.26(\mathrm{~d}, 1 \mathrm{H}, J 3.2 \mathrm{~Hz})$, $4.92(\mathrm{~d}, 1 \mathrm{H}, J 3.2 \mathrm{~Hz}), 7.26-7.34(\mathrm{~m}, 5 \mathrm{H}) \mathrm{ppm} .{ }^{13} \mathrm{C} \mathrm{NMR}\left(\mathrm{CDCl}_{3}\right): \delta 52.8(\mathrm{q}), 74.7$ (d), $75.3(\mathrm{~d})$, 126.5 (2C, d), 128.1 (d), 128.5 (2C, d), 140.3 (s), 173.4 (s) ppm. IR: $v_{\max }=3525,3051,2982$, 1737, $1263 \mathrm{~cm}^{-1}$. HRMS-EI $(\mathrm{M}++\mathrm{Na})$ : Calculated for $\mathrm{C}_{10} \mathrm{H}_{12} \mathrm{O}_{4} \mathrm{Na}$ : 219.0627, experimental: 219.0642 .

The ee value (99\%) of the diol ester 9 was determined by direct HPLC analysis on a Chiralcel OJ column: $10 \% \mathrm{CH}_{3} \mathrm{CN} / \mathrm{H}_{2} \mathrm{O}, 0.8 \mathrm{~mL} / \mathrm{min},(2 \mathrm{~S}, 3 \mathrm{R}) 11.1 \mathrm{~min},(2 \mathrm{R}, 3 \mathrm{~S}) 14.9 \mathrm{~min}$.

Methyl (4S,5R)-2,2-dimethyl-5-phenyl-1,3-dioxolane-4-carboxylate (10). A catalytic amount of $p$-toluenesulfonic acid was added to a solution of 9 (3.83 g, $19.5 \mathrm{mmol})$ and 2,2dimethoxypropane $(4.8 \mathrm{~mL}, 39.04 \mathrm{mmol})$ in $100 \mathrm{~mL}$ of $\mathrm{CH}_{2} \mathrm{Cl}_{2}$. The reaction mixture was stirred for 3 hours at room temperature. Then, $20 \mathrm{~mL}$ of a saturated aqueous solution of $\mathrm{NaHCO}_{3}$ was added and the mixture was stirred for 15 minutes. The mixture was extracted with $\mathrm{CH}_{2} \mathrm{Cl}_{2}$, the combined organic layers were washed with brine, dried over anhydrous $\mathrm{Na}_{2} \mathrm{SO}_{4}$ and the organic solvent was evaporated off under reduced pressured to afford $10(4.14 \mathrm{~g}, 90 \%)$ as a yellow oil. $[\alpha]_{\mathrm{D}}{ }^{20}:+22.3\left(\mathrm{c} 2.09, \mathrm{CHCl}_{3}\right) .{ }^{1} \mathrm{HNMR}\left(\mathrm{CDCl}_{3}\right): \delta 1.56(\mathrm{~s}, 3 \mathrm{H}), 1.62(\mathrm{~s}, 3 \mathrm{H}), 3.79(\mathrm{~s}, 3 \mathrm{H}), 4.34$ $(\mathrm{d}, 1 \mathrm{H}, J 7.8 \mathrm{~Hz}), 5.15(\mathrm{~d}, 1 \mathrm{H}, J 7.8 \mathrm{~Hz}), 7.35-7.42(\mathrm{~m}, 5 \mathrm{H}) \mathrm{ppm} .{ }^{13} \mathrm{CNMR}\left(\mathrm{CDCl}_{3}\right): \delta 26.0(\mathrm{q})$, 27.1 (q), 52.5 (q), 80.9 (d), 81.4 (d), 111.8 (s), 126.7 (2C, d), 128.7 (d), 128.8 (2C, d), 137.9 (s), 170.9 (s) ppm. IR: vmax 3424, 3056, 2988, 2930, 1731, $1265 \mathrm{~cm}^{-1}$. Analc. Calc. for $\mathrm{C}_{13} \mathrm{H}_{16} \mathrm{O}_{4}$ : C, 66.09. H, 6.83, O, 27.09. Found: C, 66.13. H, 6.80, O, 27.07.

(4S,5R)-2,2-Dimethyl-5-phenyl-1,3-dioxolane-4-carbaldehyde (11). Diisobutylaluminum hydride (17.84 $\mathrm{mL}, 1 \mathrm{M}$ in toluene) was added to a solution of $\mathbf{1 0}(2.81 \mathrm{~g}, 11.89 \mathrm{mmol})$ in dry toluene $(50 \mathrm{~mL})$ at $-78^{\circ} \mathrm{C}$ and under strict argon atmosphere. The reaction mixture was stirred for five hours at the same temperature. Then, $5 \mathrm{~mL}$ of $\mathrm{MeOH}$ and $50 \mathrm{~mL}$ of $1 \mathrm{M} \mathrm{HCl}$ were added. The mixture was stirred 30 minutes at $0{ }^{\circ} \mathrm{C}$, after which it was extracted with ethyl acetate. The combined organic layers were washed with brine, dried over anhydrous $\mathrm{Na}_{2} \mathrm{SO}_{4}$ and the organic solvent was evaporated off under reduced pressure. The crude residue was purified by flash chromatography using hexane/ethyl acetate (6:4) as eluent, to afford $\mathbf{1 1}(2.30 \mathrm{~g}, 94 \%)$ as a yellow oil. $[\alpha]_{\mathrm{D}}{ }^{20}$ : $-22.86\left(\mathrm{c} 1.12, \mathrm{CHCl}_{3}\right) .{ }^{1} \mathrm{HNMR}\left(\mathrm{CDCl}_{3}\right): \delta 1.52(\mathrm{~s}, 3 \mathrm{H}), 1.61(\mathrm{~s}, 3 \mathrm{H}), 4.18$ $\left(\mathrm{dd}, 1 \mathrm{H}, J_{1} 7.8 \mathrm{~Hz}, J_{2} 1.8 \mathrm{~Hz}\right), 5.06(\mathrm{~d}, 1 \mathrm{H}, J 7.8 \mathrm{~Hz}), 7.33-7.41(\mathrm{~m}, 5 \mathrm{H}), 9.79$ (d, 1H, J 1.8 Hz) 
ppm. ${ }^{13} \mathrm{CNMR}\left(\mathrm{CDCl}_{3}\right): \delta 26.3$ (q), 27.00 (q), 78.7 (d), 86.8 (d), 111.8 (s), 126.4 (2C, d), 128.7 (d), 128.9 (2C, d), 137.7 (s), 200.3 (d) ppm. IR: vmax 3444, 2983, 2926, 1733, $1063 \mathrm{~cm}^{-1}$. Analc. Calc. for $\mathrm{C}_{12} \mathrm{H}_{14} \mathrm{O}_{3}: \mathrm{C}$, 69.88. H, 6.84. O, 23.27. Found: C, 69.90. H, 6.87. O, 23.22.

(R)-5-((S)-((4R,5R)-2,2-dimethyl-5-phenyl-1,3-dioxolan-4-yl)(hydroxy)methyl)furan-2(5H)one (13a) and (S)-5-((S)-((4R,5R)-2,2-dimethyl-5-phenyl-1,3-dioxolan-4-yl)(hydroxy) methyl)furan-2(5H)-one (13b). Tin tetrachloride $(5.94 \mathrm{~mL}, 1 \mathrm{M}$ in dichloromethane) was added to a solution of $11(815.2 \mathrm{mg}, 3.96 \mathrm{mmol})$ in freshly distilled diethyl ether $(30 \mathrm{~mL})$ at $-78^{\circ} \mathrm{C}$ under argon atmosphere. The reaction mixture was stirred for $15 \mathrm{~min}$. and then, trimethylsilyloxyfuran $\mathbf{1 2 a}^{15}$ (783.5 $\mathrm{mg}, 3.96 \mathrm{mmol}$ ) was added. The reaction mixture was stirred for 3 hours at the same temperature after which $20 \mathrm{~mL}$ of a saturated aqueous solution of $\mathrm{NaHCO}_{3}$ were added. The mixture was warmed to room temperature and the aqueous layer was extracted with ethyl ether. The combined organic layers were washed with brine, dried over anhydrous $\mathrm{Na}_{2} \mathrm{SO}_{4}$ and concentrated under reduced pressure. The crude residue was fraccionated by flash chromatography, using hexane/ethyl acetate (1:1) as eluent, to afford 13a (514.1 mg, $46 \%)$ as a white solid and $\mathbf{1 3 b}(288.9 \mathrm{mg}, 27 \%)$ as a yellow oil.

13a. White solid Mp172-174 ${ }^{\circ} \mathrm{C} .[\alpha]_{\mathrm{D}}{ }^{20}:-44.5\left(\mathrm{c}=0.85, \mathrm{CHCl}_{3}\right) .{ }^{1} \mathrm{HNMR}\left(\mathrm{CDCl}_{3}\right): \delta 1.48(\mathrm{~s}$, $3 \mathrm{H}), 1.55$ (s, 3H), $2.65(\mathrm{~d}, 1 \mathrm{H}, J 4.0 \mathrm{~Hz}), 3.84\left(\mathrm{ddd}, 1 \mathrm{H}, J_{1} 8.4 \mathrm{~Hz}, J_{2} 8.0 \mathrm{~Hz}, J_{3} 4.0 \mathrm{~Hz}\right), 4.00$ $\left(\mathrm{dd}, 1 \mathrm{H}, J_{1} 8.4 \mathrm{~Hz}, J_{2} 7.5 \mathrm{~Hz}\right), 5.02(\mathrm{~d}, 1 \mathrm{H}, J 7.5 \mathrm{~Hz}), 5.17(\mathrm{~m}, 1 \mathrm{H}), 6.04\left(\mathrm{dd}, 1 \mathrm{H}, J_{1} 5.7 \mathrm{~Hz}, J_{2}\right.$ $2.0 \mathrm{~Hz}), 7.26-7.31(\mathrm{~m}, 3 \mathrm{H}), 7.37\left(\mathrm{dd}, 1 \mathrm{H}, J_{1} 5.7 \mathrm{~Hz}, J_{2} 1.6 \mathrm{~Hz}\right), 7.42-7.44(\mathrm{~m}, 2 \mathrm{H}) \mathrm{ppm} .{ }^{13} \mathrm{CNMR}$ $\left(\mathrm{CDCl}_{3}\right): \delta 26.9(\mathrm{q}), 27.2$ (q), 73.8 (d), 81.9 (d), 82.3 (d), 84.1 (d), 110.0 (s), 122.2 (d), 127.3 (2C, d), 128.2 (d), 128.3 (2C, d), 138.4 (s), 153.9 (d), 172.8 (s) ppm. IR: vmax 3395, 2988, 1736, $1052 \mathrm{~cm}^{-1}$. HRMS-EI $(\mathrm{M}++\mathrm{Na})$ : Calculated for $\mathrm{C}_{16} \mathrm{H}_{18} \mathrm{O}_{5} \mathrm{Na}$ : 313.1046, experimental: 313.1039.

13b. Yellow oil. $[\alpha]_{\mathrm{D}}{ }^{20}:+89.7\left(\mathrm{c} 0.725, \mathrm{CHCl}_{3}\right) .{ }^{1} \mathrm{HNMR}\left(\mathrm{CDCl}_{3}\right): \delta 1.52(\mathrm{~s}, 3 \mathrm{H}), 1.55(\mathrm{~s}, 3 \mathrm{H})$, $3.01(\mathrm{~d}, 1 \mathrm{H}, J 4.5 \mathrm{~Hz}), 3.96\left(\mathrm{dd}, 1 \mathrm{H}, J_{1} 7.5 \mathrm{~Hz}, J_{2} 6.8 \mathrm{~Hz}\right), 4.07(\mathrm{~m}, 1 \mathrm{H}), 5.06(\mathrm{~d}, 1 \mathrm{H}, J 7.5 \mathrm{~Hz})$, $5.21(\mathrm{~m}, 1 \mathrm{H}), 6.11\left(\mathrm{dd}, 1 \mathrm{H}, J_{1} 5.8 \mathrm{~Hz}, J_{2} 2.0 \mathrm{~Hz}\right), 7.30-7.45(\mathrm{~m}, 5 \mathrm{H}), 7.54\left(\mathrm{dd}, 1 \mathrm{H}, J_{1} 5.8 \mathrm{~Hz}, J_{2}\right.$ $1.4 \mathrm{~Hz}$ ) ppm. ${ }^{13} \mathrm{CNMR}(\mathrm{CDCl} 3): \delta 27.0(\mathrm{q}), 27.1(\mathrm{q}), 72.1(\mathrm{~d}), 81.2(\mathrm{~d}), 82.5(\mathrm{~d}), 83.3(\mathrm{~d}), 110.0$ (s), 122.7 (d), 127.0 (2C, d), 128.4 (d), 128.5 (2C, d), 137.9 (s), 153.8 (d), 173.0 (s) ppm. IR: vmax 3395, 2988, 1736, $1052 \mathrm{~cm}^{-1}$ HRMS-EI $(\mathrm{M}++\mathrm{Na})$ : Calculated for $\mathrm{C}_{16} \mathrm{H}_{18} \mathrm{O}_{5} \mathrm{Na}$ : 313.1046 , experimental: 313.1048 .

(S)-((4S,5R)-2,2-Dimethyl-5-phenyl-1,3-dioxolan-4-yl)((R)-5-oxo-2,5-dihydrofuran-2-yl)

methyl acetate (14a). Acetic anhydride $(139 \mu \mathrm{L}, 1.4 \mathrm{mmol})$ was added to a solution of 13a (368.3 mg, $1.27 \mathrm{mmol})$, pyridine $(150 \mu \mathrm{L}, 1.5 \mathrm{mmol})$ and a catalytic amount of DMAP in $4 \mathrm{~mL}$ of $\mathrm{CH}_{2} \mathrm{Cl}_{2}$ at room temperature. The reaction mixture was stirred for 2 hours after which crushed ice was added. The mixture was stirred for an additional hour and extracted with ethyl ether. The combined organic layers were washed successively with $1 \mathrm{M} \mathrm{HCl}$, a saturated aqueous solution of $\mathrm{NaHCO}_{3}$, brine, dried over anhydrous $\mathrm{Na}_{2} \mathrm{SO}_{4}$ and concentrated under reduced pressure. The crude residue was purified by flash chromatography, using hexane/Ethyl acetate $(1: 1)$ as eluent, to afford 14a $(0.86 \mathrm{mmol}, 68 \%)$ as a yellow oil. $[\alpha]_{\mathrm{D}}{ }^{20}:-84.4\left(\mathrm{c}=1.25, \mathrm{CHCl}_{3}\right) .{ }^{1} \mathrm{HNMR}$ $\left(\mathrm{CDCl}_{3}\right): \delta 1.45(\mathrm{~s}, 3 \mathrm{H}), 1.51(\mathrm{~s}, 3 \mathrm{H}), 1.52(\mathrm{~s}, 3 \mathrm{H}), 4.18\left(\mathrm{dd}, 1 \mathrm{H}, J_{1} 9.2 \mathrm{~Hz}, J_{2} 7.8 \mathrm{~Hz}\right), 4.68(\mathrm{~d}$, 
$1 \mathrm{H}, J 7.8 \mathrm{~Hz}$ ), $5.19\left(\mathrm{dd}, 1 \mathrm{H}, J_{1} 9.2 \mathrm{~Hz}, J_{2} 2.2 \mathrm{~Hz}\right.$ ), 5.37 (dd, 1H, $\left.J_{1} 4.0 \mathrm{~Hz}, J_{2} 2.2 \mathrm{~Hz}\right), 6.00$ (dd, $\left.1 \mathrm{H}, J_{1} 5.8 \mathrm{~Hz}, J_{2} 2.2 \mathrm{~Hz}\right), 7.24-7.29(\mathrm{~m}, 6 \mathrm{H}) \mathrm{ppm} .{ }^{13} \mathrm{CNMR}\left(\mathrm{CDCl}_{3}\right): \delta 20.4(\mathrm{q}), 27.1$ (q), 27.4 (q), 71.4 (d), 79.6 (d), 82.1 (d), 83.1 (d), 110.3 (s), 122.8 (d), 127.6 (2C, d), 128.7 (2C, d), 128.9 (d), 137.1 (s), 152.7 (d), 170.0 (s), 172.5 (s) ppm. IR: vmax 3054, 2987, 1751, 1265, 1226, 738 $\mathrm{cm}^{-1}$. HRMS-EI (M++Na): Calculated for $\mathrm{C}_{18} \mathrm{H}_{20} \mathrm{O}_{6} \mathrm{Na}$ : 355.1152, experimental: 355.1161 .

(S)-((4S,5R)-2,2-Dimethyl-5-phenyl-1,3-dioxolan-4-yl)((S)-5-oxo-2,5-dihydrofuran-2-yl)

methyl acetate $(\mathbf{1 4 b})$. Acetic anhydride $(65 \mu \mathrm{L}, 0.65 \mathrm{mmol})$ was added to a solution of $\mathbf{1 3 b}$ (126.5 mg, $0.44 \mathrm{mmol}$ ) and pyridine $(60 \mu \mathrm{L}, 0.872 \mathrm{mmol})$ in $5 \mathrm{~mL}$ of $\mathrm{CH}_{2} \mathrm{Cl}_{2}$ at room temperature. The reaction mixture was stirred for 12 hours, after which crushed ice was added. The mixture was stirred for an additional hour and extracted with ethyl ether. The combined organic layers were washed successively with $1 \mathrm{M} \mathrm{HCl}$, a saturated aqueous solution of $\mathrm{NaHCO}_{3}$, brine, dried over anhydrous $\mathrm{Na}_{2} \mathrm{SO}_{4}$ and concentrated under reduced pressure. The crude residue was purified by flash chromatography, using hexane/ethyl acetate (1:1) as eluent, to afford 14b $(0.36 \mathrm{mmol}, 82 \%)$ as a yellow oil. $[\alpha]_{\mathrm{D}}{ }^{20}:+37.0\left(\mathrm{c} 0.97, \mathrm{CHCl}_{3}\right) .{ }^{1} \mathrm{HNMR}\left(\mathrm{CDCl}_{3}\right): \delta 1.52(\mathrm{~s}$, 3H), 1.55 (s, 3H), 1.74 (s, 3H), $3.94\left(\mathrm{dd}, 1 \mathrm{H}, J_{1} 8.2 \mathrm{~Hz}, J_{2} 7.4 \mathrm{~Hz}\right), 4.90$ (d, 1H, J 8.4 Hz), 5.37 $\left(\mathrm{dd}, 1 \mathrm{H}, J_{1} 2.6 \mathrm{~Hz}, J_{2} 1.8 \mathrm{~Hz}\right), 5.44\left(\mathrm{dd}, 1 \mathrm{H}, J_{1} 7.4 \mathrm{~Hz}, J_{2} 2.6 \mathrm{~Hz}\right), 6.15\left(\mathrm{dd}, 1 \mathrm{H}, J_{1} 5.8 \mathrm{~Hz}, J_{2} 1.8\right.$ $\mathrm{Hz}), 7.31-7.34(\mathrm{~m}, 5 \mathrm{H}), 7.50(\mathrm{~d}, 1 \mathrm{H}, J 5.8 \mathrm{~Hz}) \mathrm{ppm} .{ }^{13} \mathrm{CNMR}\left(\mathrm{CDCl}_{3}\right): \delta 20.6(\mathrm{q}), 27.0(\mathrm{q}), 27.3$ (q), 71.3 (d), 80.8 (d), 81.5 (d), 82.03 (d), 110.6 (s), 123.2 (d), 127.4 (2C, d), 128.9 (2C, d), 129.0 (d), 136.7 (s), 152.4 (d), 169.6 (s), 172.4 (s) ppm. IR: vmax 2985, 2929, 1755, $1222 \mathrm{~cm}^{-1}$. HRMS-EI (M++Na): Calculated for $\mathrm{C}_{18} \mathrm{H}_{20} \mathrm{O}_{6} \mathrm{Na}$ : 355.1152, experimental: 355.1134 .

(E)-5-(((4R,5R)-2,2-Dimethyl-5-phenyl-1,3-dioxolan-4-yl)methylene)furan-2(5H)-one (15a). Diazobicycloundecane $(0.6 \mathrm{~mL}, 4.25 \mathrm{mmol})$ was added to a solution of $\mathbf{1 4 a}$ (280 $\mathrm{mg}, 0.85 \mathrm{mmol})$ in $5 \mathrm{~mL}$ of toluene under an argon atmosphere at room temperature. After $5 \mathrm{~h}$, water $(5 \mathrm{~mL})$ was added and the reaction mixture was extracted with ethyl acetate. The combined organic phases were washed with brine and dried over $\mathrm{Na}_{2} \mathrm{SO}_{4}$. Evaporation of the solvent at reduced pressure afforded a crude product, which was fractionated by flash chromatography on silica gel. Elution with ethyl acetate: hexane $=7: 3$ afforded 15a $(148 \mathrm{mg}, 65 \%){ }^{1} \mathrm{HNMR}\left(\mathrm{CDCl}_{3}\right): \delta 1.57(\mathrm{~s}, 3 \mathrm{H})$, $1.62(\mathrm{~s}, 3 \mathrm{H}), 4.46\left(\mathrm{dd}, 1 \mathrm{H}, J_{1} 8.4 \mathrm{~Hz}, J_{2} 8.0 \mathrm{~Hz}\right), 4.72(\mathrm{~d}, 1 \mathrm{H}, J 8.0 \mathrm{~Hz}), 5.73\left(\mathrm{dd}, 1 \mathrm{H}, J_{1} 8.0 \mathrm{~Hz}\right.$, $\left.J_{2} 1.4 \mathrm{~Hz}\right), 6.11\left(\mathrm{dd}, 1 \mathrm{H}, J_{1} 5.6 \mathrm{~Hz}, J_{2} 1.4 \mathrm{~Hz}\right), 7.27(\mathrm{~d}, 1 \mathrm{H}, J 5.6 \mathrm{~Hz}), 7.34(\mathrm{~m}, 5 \mathrm{H}) \mathrm{ppm}$. ${ }^{13} \mathrm{CNMR}\left(\mathrm{CDCl}_{3}\right): \delta 26.9(\mathrm{q}, 2 \mathrm{C}), 79.7$ (d), 83.3 (d), 109.7 (d), 110.2 (s), 121.3 (d), $126.3(2 \mathrm{C}$, d), 128.7 (2C, d), 128.7 (d), 135.8 (s), 140.3 (d), 151.8 (s), 168.8 (s) ppm. Analc. Calc. for $\mathrm{C}_{16} \mathrm{H}_{16} \mathrm{O}_{4}$ : C, 70.57; H, 5.92; O, 23.50. Found: C, 70.60; H, 5.87; O, 23.22.

$(E)-5-[(2 R, 3 R)-2,3-D i h y d r o x y-3-p h e n y l p r o p y l i d e n e] f u r a n-2(5 H)-o n e \quad(E)-6 . \quad$ A catalytic amount of $p$-toluensulfonic acid was added to a solution of $\mathbf{1 5 a}(50 \mathrm{mg}, 0.18 \mathrm{mmol})$ in $5 \mathrm{~mL}$ methanol. The reaction was stirred for 12 hours at room temperature. Then, the organic solvent was evaporated off under reduced pressure, $5 \mathrm{~mL}$ of water was added and the mixture was extracted with chloroform. The combined organic layers were dried over anhydrous $\mathrm{Na}_{2} \mathrm{SO}_{4}$ and concentrated under reduced pressure. The residue was purified by flash chromatography, using hexane/ethyl acetate $(3: 7)$ as eluent, to afford $(E)-6(0.13 \mathrm{mmol}, 73 \%)$ as a yellow oil. $[\alpha]_{\mathrm{D}}{ }^{20}$ : +95.5 (c 1.05, $\left.\mathrm{CHCl}_{3}\right) .{ }^{1} \mathrm{HNMR}\left(\mathrm{CDCl}_{3}\right): \delta 3.11(\mathrm{~s}, 1 \mathrm{H}), 3.36(\mathrm{~s}, 1 \mathrm{H}), 4.48\left(\mathrm{dd}, 1 \mathrm{H}, J_{1} 7.6 \mathrm{~Hz}, J_{2}\right.$ 
$7.4 \mathrm{~Hz}), 4.55(\mathrm{~d}, 1 \mathrm{H}, J 7.6 \mathrm{~Hz}), 5.55\left(\mathrm{ddd}, 1 \mathrm{H}, J_{1} 7.4 \mathrm{~Hz}, J_{2} 1.7 \mathrm{~Hz}, J_{3} 0.5 \mathrm{~Hz}\right), 6.05\left(\mathrm{dd}, 1 \mathrm{H}, J_{1}\right.$ $\left.5.6 \mathrm{~Hz}, J_{2} 1.7 \mathrm{~Hz}\right), 7.27-7.34(\mathrm{~m}, 5 \mathrm{H}), 7.47\left(\mathrm{dd}, 1 \mathrm{H}, J_{1} 5.6 \mathrm{~Hz}, J_{2} 0.5 \mathrm{~Hz}\right) \mathrm{ppm} .{ }^{13} \mathrm{CNMR}$ $\left(\mathrm{CDCl}_{3}\right): \delta 73.1$ (d), 77.7 (d), 112.7 (d), 120.9 (d), 126.7 (2C, d), $128.6(\mathrm{~d}), 128.6$ (2C, d), 139.1 (s), 140.9 (d), 151.4 (s), 169.2 (s) ppm. IR: vmax 3403, 1776, 1747, $1060 \mathrm{~cm}^{-1}$. HRMS-EI $(\mathrm{M}++\mathrm{Na})$ : Calculated for $\mathrm{C}_{13} \mathrm{H}_{12} \mathrm{O}_{4} \mathrm{Na}$ : 255.0627, experimental: 255.0628.

$(5 R, 7 R, 8 S, 9 S)-9-B r o m o-8-h y d r o x y-7-p h e n y l-1,6-d i o x a s p i r o[4.4]$ non-3-en-2-one $(7 a)$ and $(5 R, 7 R, 8 S, 9 R)$-9-bromo-8-hydroxy-7-phenyl-1,6-dioxaspiro[4.4]non-3-en-2-one (7b). A solution of (E)-6 $(122.4 \mathrm{mg}, 0.52 \mathrm{mmol})$ in $5 \mathrm{~mL}$ of $\mathrm{CHCl}_{3}$ was placed in a $50 \mathrm{~mL}$ roundbottommed flask. The solution was cooled to $0{ }^{\circ} \mathrm{C}$, after which NBS (140 mg, $0.8 \mathrm{mmol}$ ) and $\mathrm{NaHCO}_{3}(65.6 \mathrm{mg}, 0.8 \mathrm{mmol})$ were added. After 48 hours the reaction was completed and $5 \mathrm{~mL}$ of $\mathrm{CHCl}_{3}$ was added. The organic solution washed successively with an aqueous $10 \% \mathrm{Na}_{2} \mathrm{~S}_{2} \mathrm{O}_{3}$ solution, followed by brine and dried over anhydrous $\mathrm{Na}_{2} \mathrm{SO}_{4}$. Evaporation of the solvent under reduced pressure afforded a residue $(200 \mathrm{mg})$, which was fractionated by flash chromatography with hexane/ethyl acetate $(1: 1)$ as eluent mixture, to afford $105.2 \mathrm{mg}(65 \%)$ of mixture of $7 \mathbf{a}$ and 7b (3: 1).

7a. Colorless oil, ${ }^{1} \mathrm{HNMR}\left(\mathrm{CDCl}_{3}\right): \delta 4.62(\mathrm{~m}, 1 \mathrm{H}), 4.82(\mathrm{~d}, 1 \mathrm{H}, J 4.0 \mathrm{~Hz}), 5.51(\mathrm{~d}, 1 \mathrm{H}, J 4 \mathrm{~Hz})$, $6.20\left(\mathrm{dd}, 1 \mathrm{H}, J_{1} 5.5 \mathrm{~Hz}, J_{2} 1.0 \mathrm{~Hz}\right), 7.37-7.42(\mathrm{~m}, 5 \mathrm{H}), 7.44\left(\mathrm{dd}, 1 \mathrm{H}, J_{1} 5.5 \mathrm{~Hz}, J_{2} 1.0 \mathrm{~Hz}\right) \mathrm{ppm}$. ${ }^{13} \mathrm{CNMR}\left(\mathrm{CDCl}_{3}\right): \delta 54.9$ (d), 73.5 (d), 83.5 (d), 113.4 (s), $123.4(\mathrm{~d}), 126.8(2 \mathrm{C}, \mathrm{d}), 128.5(2 \mathrm{C}$, d), 128.8 (d), 133.9 (s), 152.4 (d), 169.2 (s) ppm. HRMS-EI (M++Na): Calculated for $\mathrm{C}_{13} \mathrm{H}_{11} \mathrm{O}_{4} \mathrm{BrNa}$ : 332.973291, experimental: 332.9742.

7b. Colorless oil, ${ }^{1} \mathrm{HNMR}\left(\mathrm{CDCl}_{3}\right): \delta 4.48(\mathrm{~s}, 1 \mathrm{H}), 4.61(\mathrm{~m}, 1 \mathrm{H}), 5.91(\mathrm{~d}, 1 \mathrm{H}, J 4.3 \mathrm{~Hz}), 6.31$ $\left(\mathrm{dd}, 1 \mathrm{H}, J_{1} 5.7 \mathrm{~Hz}, J_{2} 1.0 \mathrm{~Hz}\right), 7.37-7.42(\mathrm{~m}, 5 \mathrm{H}), 7.5(\mathrm{~d}, 1 \mathrm{H}, J 5.7 \mathrm{~Hz}) \mathrm{ppm} .{ }^{13} \mathrm{CNMR}\left(\mathrm{CDCl}_{3}\right): \delta$ 54.8 (d), 79.4 (d), 86.5 (d), 114.3 (s), 125.4 (d), 126.5 (2C, d), 128.6 (2C, d), 128.7 (d), 134.0 (s), 151.6 (d), 170.7 (s) ppm. HRMS-EI (M++Na): Calculated for $\mathrm{C}_{13} \mathrm{H}_{11} \mathrm{O}_{4} \mathrm{BrNa}$ : 332.9733, experimental: 332.9742 .

(+)-8-epi-Crassalactone D and 5,8-epi-crassalactone D (1b and 1c). A solution of a mixture of bromolactones 7a and 7b. $(3: 1)(62.8 \mathrm{mg}, 0.2 \mathrm{mmol})$ in toluene $(6 \mathrm{~mL})$ was placed in a $50 \mathrm{~mL}$ round-bottomed-flask. The solution was kept in an inert atmosphere and warmed to reflux temperature. At this temperature a catalytic amount of AIBN was added and shortly after $\mathrm{Bu}_{3} \mathrm{SnH}(64 \mu \mathrm{L}, 0.24 \mathrm{mmol})$ was added dropwise. The reaction mixture was stirred at the same temperature for $25 \mathrm{~min}$, after which it was cooled to room temperature. Then, the mixture was poured over a saturated aqueous solution of $\mathrm{NaF}$. The solution was stirred for $4 \mathrm{~h}$, extracted with ethyl acetate, washed with brine, dried over anhydrous $\mathrm{Na}_{2} \mathrm{SO}_{4}$, and concentrated under reduced pressure. The residue was purified by flash chromatography, using hexane/ethyl acetate (1:1) as eluent, to afford $\mathbf{1 b}(35 \mathrm{mg}, 75 \%)$ and $\mathbf{1 c}(11.5 \mathrm{mg}, 25 \%)$.

1b. Colorless oil, $[\alpha]_{\mathrm{D}}{ }^{20}:-20.6\left(\mathrm{c} 0.82, \mathrm{CHCl}_{3}\right) .{ }^{1} \mathrm{HNMR}\left(\mathrm{CDCl}_{3}\right): \delta 2.53\left(\mathrm{dd}, 1 \mathrm{H}, J_{1} 14.7 \mathrm{~Hz}, J_{2}\right.$ $1.1 \mathrm{~Hz}), 2.81\left(\mathrm{dd}, 1 \mathrm{H}, J_{1} 14.7 \mathrm{~Hz}, J_{2} 5.3 \mathrm{~Hz}\right), 4.62-4.65(\mathrm{~m}, 1 \mathrm{H}), 5.43(\mathrm{~d}, 1 \mathrm{H}, J 3.1 \mathrm{~Hz}), 6.16$ (dd, $\left.1 \mathrm{H}, J_{1} 5.5 \mathrm{~Hz}, J_{2} 1.1 \mathrm{~Hz}\right), 7.36-7.38(\mathrm{~m}, 5 \mathrm{H}), 7.38(\mathrm{~d}, 1 \mathrm{H}, J 5.5 \mathrm{~Hz}) \mathrm{ppm} .{ }^{13} \mathrm{CNMR}\left(\mathrm{CDCl}_{3}\right): \delta$ 43.1 (t), 73.7 (d), 86.6 (d), 113.6 (s), 122.7 (d), 126.6 (2C, d), 128.6 (d), 128.7 (2C, d), 134.1 (s), 
152.9 (d), 169.9 (s) ppm. IR: vmax 3463, 3052, 2984, 1768, 1264, 1168, $1028 \mathrm{~cm}^{-1}$. HRMS-EI $(\mathrm{M}++\mathrm{Na})$ : Calculated for $\mathrm{C}_{13} \mathrm{H}_{12} \mathrm{O}_{4} \mathrm{Na}: 255.0628$, experimental: 255.0621 .

1c. Colorless oil, $[\alpha]_{\mathrm{D}}{ }^{20}$ : $-16.8\left(\mathrm{c} 0.56, \mathrm{CHCl}_{3}\right)$. ${ }^{1} \mathrm{HNMR}\left(\mathrm{CDCl}_{3}\right): \delta 2.54(\mathrm{~d}, 1 \mathrm{H}, J 14.0 \mathrm{~Hz}), 2.63$ $\left(\mathrm{dd}, 1 \mathrm{H}, J_{1} 14.0 \mathrm{~Hz}, J_{2} 4.8 \mathrm{~Hz}\right), 4.59-4.61(\mathrm{~m}, 1 \mathrm{H}), 5.40(\mathrm{~d}, 1 \mathrm{H}, J 4.1 \mathrm{~Hz}), 6.25\left(\mathrm{~d}, 1 \mathrm{H}, J_{1} 5.6\right.$ $\mathrm{Hz}), 7.21(\mathrm{~d}, 1 \mathrm{H}, J 5.6 \mathrm{~Hz}), 7.40-7.43(\mathrm{~m}, 5 \mathrm{H}) \mathrm{ppm} .{ }^{13} \mathrm{CNMR}\left(\mathrm{CDCl}_{3}\right): \delta 40.3(\mathrm{t}), 72.8(\mathrm{~d}), 88.9$ (d), 114.0 (s), 124.4 (d), 126.6 (2C, d), 128.3 (d), 128.5 (2C, d), 135.1 (s), 151.6 (d), 169.1 (s) ppm. IR: vmax 3463, 3054, 2986, 1776, 1422, $1265 \mathrm{~cm}^{-1}$. HRMS-EI (M++Na): Calculated for $\mathrm{C}_{13} \mathrm{H}_{12} \mathrm{O}_{4} \mathrm{Na}$ : 255.0628, experimental: 255.0614.

(+)-Crassalactone D benzoate (18). Triphenylphosphine $(34.6 \mathrm{mg}, 0.13 \mathrm{mmol})$ and benzoic acid (16.1 mg, $0.13 \mathrm{mmol})$ were added to a solution of $\mathbf{1 b}(25 \mathrm{mg}, 0.11 \mathrm{mmol})$ in $2 \mathrm{~mL}$ of freshly distilled THF. The solution was kept at room temperature in an inert atmosphere and then diethyl azodicarboxylate (DEAD) (40\% in THF) $(60 \mu \mathrm{L}, 0.13 \mathrm{mmol})$ was added dropwise. The reaction mixture was stirred for 24 hours at the same temperature and then concentrated under reduced pressure. The residue was fractionated by flash chromatography, using hexane/ethyl acetate (6:4) as eluent mixture, to afford $18(28.6 \mathrm{mg}, 75 \%)$.

$[\alpha]_{\mathrm{D}}{ }^{20}:+22.8\left(\mathrm{c} 0.25, \mathrm{CHCl}_{3}\right) .{ }^{1} \mathrm{HNMR}\left(\mathrm{CDCl}_{3}\right): \delta 2.51\left(\mathrm{dd}, 1 \mathrm{H}, J_{1} 14.8 \mathrm{~Hz}, J_{2} 1.5 \mathrm{~Hz}\right), 2.75(\mathrm{dd}$, $\left.1 \mathrm{H}, J_{1} 14.8 \mathrm{~Hz}, J_{2} 6.8 \mathrm{~Hz}\right), 5.56$ (ddd, $\left.1 \mathrm{H}, J_{1} 6.8 \mathrm{~Hz}, J_{2} 2.7 \mathrm{~Hz}, J_{3} 1.5 \mathrm{~Hz}\right), 5.64$ (d, 1H, J 2.7 Hz), $6.31(\mathrm{~d}, 1 \mathrm{H}, J 5.6 \mathrm{~Hz}), 7.32(\mathrm{~d}, 1 \mathrm{H}, J 5.6 \mathrm{~Hz}), 7.42-7.51(\mathrm{~m}, 10 \mathrm{H}) \mathrm{ppm} .{ }^{13} \mathrm{CNMR}\left(\mathrm{CDCl}_{3}\right): \delta 40.2$ (t), 79.3 (d), 88.1 (d), 113.7 (d), 125.0 (d), 125.3 (d), $128.4(2 \mathrm{C}, \mathrm{d}), 128.5(2 \mathrm{C}, \mathrm{d}), 128.7$ (2C, d), 129.3 (s), 129.9 (2C, d), 130.1 (d), 137.8 (s), 151.0 (d), 166.2 (s), 169.6 (s) ppm. HRMS-EI $(\mathrm{M}++\mathrm{Na})$ : Calculated for $\mathrm{C}_{20} \mathrm{H}_{16} \mathrm{O}_{5} \mathrm{Na}$ : 359.0890, experimental: 359.0891 .

\section{Acknowledgements}

R.G-F and D.C-T wish to thank FSE (European Social Fund) and the Education Council of the Regional Government of Castile \& León, Spain for predoctoral grants. The Gadea Group, Crystal Pharma, Parque Tecnológico de Boecillo, Valladolid Spain, is acknowledged for financial aid for this project.

\section{References}

1. (a) Ireland, R. E.; Thompson, W. J. J. Org. Chem. 1979, 44, 3041-3052. (b) Ireland, R. E.; Varney, M. D. J. Org. Chem. 1986, 51, 635- 648. (c) Gripenberg, J. Acta Chem. Scand. 1981, 35, 513-519.

2. (a) Tuchinda, P.; Munyoo, B.; Pohmakotr, M.; Thinapong, P.; Sophasan, S.; Santisuk, T.; Reutrakul, V. J. Nat. Prod. 2006, 69, 1728-1733.

3. Nukina, M.; Hirota, H. Biosci. Biotech. Biochem. 1992, 56, 1158-1159. 
4. Engstrom, K. M.; Mendoza, M. R.; Navarro-Villalobos, M.; Gin, D.Y. Angew. Chem. Int. Ed. Engl. 2001, 40, 1128-1130.

5. Oh, H.; Gloer, J. B.; Shearer, C. A. J. Nat. Prod. 1999, 62, 497-501.

6. Massias, M.; Rebuffat S.; Molho, L.; Chiaroni, A.; Riche, C.; Bodo, B. J. Am. Chem. Soc. 1990, 112, 8112-8115.

7. Macias, F. A.; Varela, R. M.; Simonet, A. M.; Cutler, H. G.; Cutler, S. J.; Hill, R. A. Tetrahedron Lett. 2003, 44, 941-943.

8. Knight, D. W. Contemp. Org. Synth. 1994, 287-315.

9. (a) Mellor, J. M.; Mohammed, S. Tetrahedron Lett. 1991, 32, 7107-7110. (b) Alonso, D.; Font, J.; Ortuño, R. M. J. Org. Chem. 1991, 56, 5567-5572. (c) Paquette, L. A.; Owen, D. R.; Bibart, R. T.; Seekamp, C. K.; Kahane, A.L.; Lanter, J. C.; Alvarez-Corral, M. J. Org. Chem. 2001, 66, 2828-2834. (d) Langer, P.; Albrecht, U.; Synlett 2002, 1841-1842. (e) Chen, L.; Xu, H-H.; Hu, T-S; Wu, Y-L. Pest Manag. Sci. 2005, 61, 477-482. (f) Zard, S. Z.; Guindeuil, S. Chem. Commun. 2006, 665-667. (g) Maulide, N.; Markó, E. Org. Lett. 2006, 3705-3707. (h) Yang, Y-H; Shi, M. Org. Lett. 2006, 8, 1709-1712. (i) Song, F.; Liu, Y. J. Organomet. Chem. 2009, 694, 502-509.

10. Robertson, J.; Stevens, K.; Naud, S. Synlett 2008, 2083-2086.

11. Paviakos, E.; Georgiou, T.; Tofi, M.; Montagnon, T.; Vassilikogiannakis, G. Org. Lett. 2009, 11, 4556-4559.

12. Yang, Z.; Tang, P.; Gauuan, J. F.; Molino, B. F. J. Org. Chem. 2009, 74, 9546-9549.

13. (a) Lee, A.W.M.; Martin V. S.; Masamune, S. J. Am. Chem. Soc. 1982, 104, 3515-3516. (b) Zhou, W-S.; Yang, Z-C. Tetrahedron Lett. 1993, 34, 7075-7076. (c) Xu, D.; Sharpless, B. Tetrahedron Lett. 1994, 35, 4685-4688. (d) Ko, S. Y.; Lerpiniere, J. Tetrahedron Lett. 1995, 36, 2101-2104.

14. For general references on vinylogous and related reactions, see: (a) Casiraghi, G.; Battistini, L.; Curti, C.; Rassu, G.; Zanardi, F. Chem. Rev. 2011, 111, 3076-3154. (b) Casiraghi, G.; Zanardi, F.; Appendino, G.; Rassu, G. Chem. Rev. 2000, 100, 1929-1972.

15. Theoretical ab-initio calculations have been performed by using the MM2 interface of ChemBio 3D Ultra 11.0.

16. For E1cb elimination processes see: Rico, R.; Bermejo F. Tetrahedron Lett. 1996, 37, 5809-5812

17. Bartlett, P.A. Tetrahedron 1980, 36, 2-72.

18. (a) Martin, M. J.; Bermejo, F. Tetrahedron Lett. 1995, 36, 7705-7708. (b) Martin, M. J.; Bermejo, F. Tetrahedron 1998, 54, 12379-12388.

19. (a) Varasi, M.; Walter, K. A. M.; Maddox, M. L. J. Org. Chem. 1987, 52, 4235-4238. (b) Store, G.; West, F.; Lee, H. Y.; Isaacs, R. C. A.; Manabe, S. J. Am. Chem. Soc. 1996, 118, 10660-10661. 